\title{
Anti-Corruption Values Civilization Management Model in the Program of Strengthening Character Education in Public Primary Schools in Gorontalo Regency
}

\author{
Irmawati Duko Ishak \\ Universitas Muhammadiyah Gorontalo, Indonesia \\ email: irmawatiishak@gmail.com
}

\begin{abstract}
This study is about a model of civilizing anti-corruption values in the implementation of programs to strengthen character education in public elementary schools in the district. Gorontalo. The main target of this research is to design a model of the civilization of anti-corruption values in the implementation of character education strengthening programs that can produce products in the form of books to guide educators, parents and the public, especially in Gorontalo district in implementing anti-corruption values which lead to the creation of anti-corruption characters. This research applies the research and development approach. This research also answers specific questions of practical problems through "applied research" to improve educational practices. The study, conducted in January to July 2019, began with collecting initial information through observations in public elementary schools in Gorontalo district, and from various other sources such as the education office, principals, educators, students, parents, and the community. The implementation of the research through stages, preparation begins with the initial observation of the implementation of strengthening character education in schools, collecting data, interviewing analyzing data, reviewing and verifying data, preparing reports, and publicizing. This research uses a data triangulation technique that is combining 3 data collection techniques (observation, interview, and documentation) data analysis carried out during the process in the field together with data collection.
\end{abstract}

Keywords: anti-corruption, character, civilization.

\section{A. INTRODUCTION}

Corruption is called an extraordinary crime that requires extraordinary handling efforts. Corruption is a social disease (social pathology) that results in material and financial losses. Corruption is an act of abuse of authority or political resources for personal or group interests. A survey of transparency institutions indicates that corruption in Indonesia is quite high. Based on the results of a report conducted by the World Justice Project (WPJ), it shows that Indonesia was ranked 14th out of the 15 most corrupt countries in the world and ranked 80th out of 90 countries in the world. (WJP, 2015:13) Handling corruption in Indonesia Corruption Watch (ICW) states that throughout 2015 there were 550 total corruption cases. Of the 550 cases, 369 cases were handled by the Prosecutor's Office, 151 cases by the Police and 30 cases by the Corruption Eradication Commission. In addition, state losses due to corruption cases during the first semester of 2015 amounted to Rp.1.2 trillion and losses during the 
second semester increased to 1.8 trillion. A total of 1,124 people were named suspects in the 550 cases (Anticorruption, 2016). In 2017 Indonesia was in the sixth most corrupt position in the world. The Indonesian Corruption Perception Index (CPI) score in 2017 was 37 and was ranked 96th out of 180 countries surveyed. Indonesia's CPI score is at the same point as in 2016. Indonesia's CPI score is at the same point as in 2016. A total of 1,124 people are suspected in these 550 cases (Anti-Corruption, 2016).

The implementation of this research was carried out in public elementary schools in Gorontalo Regency, namely SD Negeri 1 Limboto, SD Negeri 2 Telaga and SD Negeri 9 Limboto. The selected school is a school that carries out the strengthening of character education. Based on the description of the background of the problem above, identification of problems is as follows: Low knowledge and understanding of students towards anti-corruption character education, Implication The program to strengthen character education in elementary schools has not fully touched anti-corruption character education, the school environment has not been maximized by teachers as the environment for implementing anti-corruption character education, students often cheat in the form of cheating and coming late, low motivation of principals, teachers and students in implementing anti-corruption education, lack of interest in schools establishing honesty canteens as anti-corruption education laboratories, absence of education management models the character of anti-corruption which is a guide for schools in implementing anti-corruption character education, anti-corruption character education in primary schools is still limited to theory or learning not yet entered the implementation stage and habituation so students still do not fully understand what anti-corruption character education is.

The purpose of this study was to determine the anti-corruption values civilization management model in strengthening character education programs, in public elementary schools in Gorontalo District.

\section{B. LITERATURE REVIEW}

Cultivation means a higher level of correctional, it can be said that maintaining and maintaining values is maintained and carried out as it should. Penitentiary is to socialize to all citizens about the values that need to be known, as well as various problems that may arise in implementing such fundamental values for the life of the community, nation, and state. Culture, as taught in the psychology of education, is more advanced because encouragement provides motivation. Viewed in terms of motoric nuances on civilization higher than correctional more at the level of positive and effective. In prisons, it also contains demands on how to civilize it, but it can be felt that this orientation to civilization also involves institutionalization in the community (Purwito, 2016).

This culture means the process of civilization or the process experienced in studying cultural systems. Cultivation in the simplest sense is the birth of habituation in another sense of activity, willingness, arousing oneself to achieve the best desires (Marwi, 2012). According to Budiharjo Andreas (2011:177) Cultivation systematically and thoroughly is done so that these values are lived out, adhered to and implemented and become the basis of behavior. The way of civilization is more human with the 
dignity of the nation through the convergence between thinking, sensory (sensing), conscience (feeling, intuition) and belief in God Almighty (beliving) (Wuryudi, 2013). Corruption is literally decayed, ugliness, depravity, dishonesty, can be bribed, immoral, deviations from holiness (Karsona, 2013: 23). Corruption is bad deeds, embezzlement of money, acceptance of bribes, and so on to enrich oneself, others, which results in the loss of state finances, which are carried out by people who have interests or power (Rosikah, 2016: 3). Maheka (2014: 23-24) gives reasons for the causes of corruption, including the culture of member tribute, rewards for services and gifts, and the culture of permissiveness, not wanting to know: consider normal if there is corruption, because it often occurs. No matter other people, as long as their own interests are protected. The act of corruption is influenced by internal and external factors. Prevention efforts are needed through the two factors that cause corruption. According to Rosikah (2016:67), Anti-corruption values that are firmly embedded in individuals prevent acts of corruption internally. Anti-corruption values include honesty, independence, discipline, responsibility, hard work, simplicity, courage, and justice.

Culture in this study means the civilizing process or the process experienced in studying cultural systems. Cultivation in the simplest sense is the birth of habituation in another sense of activity, willingness, arousing oneself to achieve the best desires (Sutijono, 2015). According to Budiharjo Andreas (2011:177) Culturing systematically and thoroughly is done so that these values are lived out, adhered to and implemented and become the basis of behavior. The way of civilization is more human with the dignity of the nation through the convergence between thinking, sensory (sensing), conscience (feeling, intuition) and belief in God Almighty (beliving) (Wuryudi, 2013).

According to Rosikah (2016: 67), Anti-corruption values that are firmly embedded in individuals prevent acts of corruption internally. Anti-corruption values include honesty, independence, discipline, responsibility, hard work, simplicity, courage, and justice.

The hypothesis offered by this study is:

1. Improving the quality of Indonesian human resources through moral intelligence in preventing acts of corruption in Indonesia through a strategic approach that suits the needs of elementary school students.

2. The ideal description of the civilization model of anti-corruption values can be generated through studies and scientific synergies between the description of the target program which is the object of discussion with the support of theories that are relevant to the scientific substance.

3. That is the life of the elementary school community, especially students, there are always cultural values that are maintained and become part of the habit that functions as a criterion to be used in choosing the goals of his life in the future.

4. Efforts to carry out human resource development programs in the field of education are always based on the goals of national education as the basis for the management of education both in sectoral and program levels. Efforts to achieve the national education target are the basis for the violation of educational programs related to anti-corruption prevention which in turn forms an anti-corruption attitude. 


\section{METHOD}

The research activities of the management model of empowering anti-corruption values in the character education strengthening program (PPK), in public elementary schools in Gorontalo District are designed by applying a research and development approach. Borg and Gall in Hamid (2014: 136) argue that research and development (R\&D) is a strategy that aims to improve the quality of education. Research using the R\&D approach aims to develop and validate educational outcomes and discover new knowledge through Basic Research. Furthermore, with the development of a civilization management model that has anti-corruption values in elementary schools, it is based on the consideration that the assessment of this model can: 1) provide a general picture of the activities carried out so that changes in anti-corruption cultural values are expected. 2) shows the habituation program activities in the activities of civilizing anti-corruption values.

The first activity, this research was carried out exploratively-qualitatively carried out with the following steps:

1. Phase 1 research: Preliminary study: This activity is a preliminary study that aims to reflect the situation that occurred in the field. Through these activities, various facts and phenomena related to 1) a general description of the objective conditions of public elementary schools in the District will be explored. Gorontalo, 2) Model of acculturation of anti-corruption character values for students in character education strengthening programs, 3) Implementation of civilization activities programs for anti-corruption character values, steps, strategy approaches, and empowerment of school human resources. In this preliminary study, a description of the condition of public elementary schools that are the location of research found by researchers, this school has implemented a program to strengthen character education but has not touched anti-corruption values specifically. So that a more specific program is needed that is related to civilizing anti-corruption values.

2. Preparation of the conceptual model: in the preparation of the conceptual model always refers to the results of the initial study or preliminary study. At this stage, a conceptual management model for the civilization of anti-corruption values was developed.

3. Activity validation/verification of conceptual models: The conceptual model that has been prepared is validated/verified by involving experts in the field of character and anti-corruption education, KPK resource persons and legal and educational figures. This process aims to perfect the conceptual model carried out through seminars, exchange of opinions and its kind.

4. Revision of the conceptual model: Revision of the model is based on suggestions and input from experts and practitioners, and is supported by reading sources in the form of literature and research results.

D. RESULTS AND DISCUSSION

First: The reference model and realistic model of the Cultivation Management of 
Anti-Corruption Values in State Elementary School in Gorontalo Regency, there has not yet been a real model of management of civilizing anti-corruption values while the model that has been formed relating to anti-corruption values is a model of the application of character education but it has not fully touched anti-corruption values. The reference framework for the civilization program of anti-corruption values in this study refers to the reality model of Cultivating Morals in Primary Schools, namely.

The implementation of the civilization model of anti-corruption values is carried out through three approaches, namely: (1) the approach to learning integration, (2) school environment arrangement, and (3) integration of extra-curricular programs. The concept of the civilization model approach is explained in each meeting formulating the Education Unit Level Curriculum (KTSP) at the beginning of the school year. The implementation of the Principal always gives direction to the importance of integrating anti-corruption values, sourced from religion as well as from the nation's philosophy, Pancasila, in learning activities in the classroom and in the classroom. But in practice, the teacher only integrates direct integration of anti-corruption values and anti-corruption values in Civics (Citizenship Education) subjects and Islamic and Christian religious education. In other subjects, anti-corruption values are integrated indirectly (indirect integration), carried out when opening and closing learning activities, certain subjects that very intersect with moral values, and when giving direction to students who commit violations in class. In other words, subject teachers outside the Civics and Religion do not explicitly include anti-corruption values in the syllabus and RPP (Learning Implementation Plan) that they design, anti-corruption values only become a nurturant effect for subjects outside of Civics and Religion. In the implementation process, there are still some weaknesses such as the inconsistency of teacher attitudes and behaviors that sometimes do not describe the moral messages instilled in students which have an impact on the bias of the embedded values of students.

The approach related to structuring the school environment is grouped into physical and non-physical environmental arrangements. This is evident in the green schoolyard arrangement, adequate learning facilities and infrastructure, worship facilities, conducive classroom arrangement, hygiene facilities, complete supporting facilities in each room, and making moral messages displayed on each classroom wall and existing room. Whereas the arrangement of non-physical elements includes the formulation of the vision, mission, program, and school order that are operationally elaborated in the vision, mission, program, and class rules, as well as each unit in the school such as an extra-curricular, library.

Regarding the approach to extracurricular activities namely utilizing extracurricular programs in the school, it can be explained that there are 2 extra activities carried out by the school, namely before the learning activities begin with the form of joint literacy activities, prayer together and extra activities after learning activities namely scout and sports activities.

Second: Hypothetical management model for civilizing anti-corruption values in elementary schools. Based on the model of civilization's reliance on anti-corruption values in Elementary Schools, the more comprehensive model is used as a reference. 
The hypothetical alternative model can be described as follows:

1. Approach to integration in all subjects: Anti-corruption values can be integrated into all subjects. Realizing the teacher needs to be given education and training and assistance on an ongoing basis to integrate anti-corruption values which are about learning design, whether syllabus or RPP (Learning Implementation Plan) so that anti-corruption values are explicitly planned in all learning components (goals, material, methods, media, source, and evaluation) on all subjects.

2. Approach to structuring the school atmosphere. The design of the school atmosphere arrangement is contained in the terms of reference of the Ministry of National Education as well as structuring the atmosphere of the school that develops in state elementary school. what needs to be developed from both is the conducive indicator of the school atmosphere, including the establishment of a school atmosphere oriented to the formation of a religious atmosphere, a nationalist atmosphere, an independent atmosphere, a democratic atmosphere, a fair atmosphere, a mutual cooperation atmosphere, a full atmosphere reforestation, a clean and tidy atmosphere, an atmosphere full of cooperation and togetherness and an atmosphere full of moral messages.

3. Approach to setting the atmosphere around the school. Structuring the atmosphere outside the school is needed because schools need to build synergic relationships between life in school and outside school and vice versa.

4. Approach to the development of extra-curricular programs. extracurricular development at Public Elementary Schools in Telaga 2 Elementary School, Limboto 9 Elementary School, and Limboto State Elementary School 2 become a reference for other school programs in developing character education reinforcement namely activities before learning begins and after learning begins. But informing the character of anti-corruption, additional methods are needed that can attract students 'attention, so it is necessary to add literacy activities to anti-corruption books and also requires a storytelling method by teachers.

5. Approach to developing anti-corruption practice activities. In the approach to developing anti-corruption, it is the honesty canteen where students can buy in the school canteen without guards, then the students themselves pay and make a change. The following practice is the kejujuran garden, where each student is required to plant trees in the garden of honesty, then given the name of the student, the student is obliged to water and care for the tree until the tree grows. The next practice is caring for others, namely the school providing a place in front of the school to share free rice packs for people in need.

\section{E. CONCLUSION}

The acculturation of anti-corruption values in Elementary Schools requires integrated program management since the formulation of the vision, mission, and school policies that are held simultaneously through the integration of all learning components, structuring the school atmosphere both physically and non-physically in the classroom and school environment, developing curricular activities, co-curricular and extra-curricular activities, as well as the synergy between the school and the 
community.

Development of civilizing management of anti-corruption values in Elementary Schools needs to be done since curriculum planning then organizes curricula, develops teaching materials, management of classes and school environments, and systemic guidance for all education stakeholders, so that there is a unified program, steps, and actions between activities in the classroom, in the school environment, and the environment around the school.

The principal should design a program to improve teacher competence in developing student character, especially the character of anti-corruption. Teacher-specific training related to approaches to value education and strategies for integrating corruption values into learning designs, both Syllabus and RPP (Learning Implementation Plans) become one of the basic needs that need to be facilitated by the Principal through the MGMP forum or cluster organization. in elementary school. So that teachers have an integrity that is not only capable of transferring knowledge but also transforming student values.

\section{REFERENCES}

1. Maheka, A. (2014). Mengenali dan Memberantas Korupsi. Jakarta: Komisi Pemberantasan Korupsi.

2. Budiharo, A. (2011). Organisasi Menuju Pencapaian Kinerja Optimum Sintesis Teori Untuk Mengungkap Kotak Hitam Organisasi. Jakarta: Prasetya Mulya Publishing

3. Chatrina Darul Rosikah. 2016. Pendidikan Anti Korupsi Kajian Anti Korupsi Teori dan Praktik. Jakarta: Sinar Grafika.

4. Hamid, I. A. 2014. Analisis Pengembangan Kompetensi Pamong Belajar di BPKB Propinsi Gorontalo. Penelitian Internal Dosen Fakultas Ilmu Pendidikan UNG.

5. Karsona, A. M. (2011). Pengertian Korupsi dalam Buku Pendidikan Anti Korupsi Untuk Perguruan Tinggi. Jakarta: Komisi Pembenrantasan Anti Korupsi.

6. Marwi, T. I., \& Sutijono. (2012). Penggunaan Strategi Pengelolaan Diri (Self-Management) Untuk Mengurangi Tingkat Kemalasan Belajar. Jurnal Psikologi Pendidikan dan Bimbingan, 13(1), 11-19.

7. Purwito. (2016). Pembudayaan Nilai-Nilai Pancasila Bagi Masyarakat Sebagai Modal Dasar Pertahanan Nasional NKRI. Jurnal Moral Kemasyarakatan, 1(1).

8. Sutijono, et al. (2015). Praksis semangat pagi universitas PGRI Adibuana Surabaya, suatu keniscayaan membawa universitas PGRI Adibuana Surabaya mandiri dan bermartabat. Yogyakarta: Andi Offset.

9. Wuryudi. (2013). Strategi Pembudayaan Nilai-Nilai Pancasila Dibindang Pendidikan dan Kebudayaan Dalam Perspektif Keindonesiaan. Proceeding Kongres Pancasila V. 